\title{
Gene expression plasticity in Pocillopora corals from 2 locations on the Carrizales Reef, Pacific coast of Mexico
}

\section{Plasticidad de la expresión génica en corales Pocillopora de 2 localidades del arrecife Carrizales, costa mexicana del Pacífico}

\author{
M Alejandro Delgadillo-Nuño ${ }^{1}$, Marco A Liñán-Cabello ${ }^{2}$, Erick Delgadillo-Nuño ${ }^{3}$, \\ Clara E Galindo-Sánchez ${ }^{3}$, Eugenio de Jesús Carpizo-Ituarte ${ }^{1 *}$ \\ ${ }^{1}$ Instituto de Investigaciones Oceanológicas, Universidad Autónoma de Baja California, km 103 Carretera \\ Tijuana-Ensenada, CP 22860, Ensenada, Baja California, Mexico. \\ 2 Acuacultura/Biotecnología, Facultad de Ciencias Marinas, Universidad de Colima, km 19.5 Carretera \\ Manzanillo-Barra de Navidad, CP 28868, Manzanillo, Colima, Mexico. \\ 3 Departamento de Biotecnología Marina, Centro de Investigación Científica y de Educación Superior de \\ Ensenada, CP 22860, Ensenada, Baja California, Mexico.
}

* Corresponding author. E-mail: ecarpizo@uabc.edu.mx

\begin{abstract}
The greatest threat scleractinian corals face today is accelerated climate change. Assuming that most scleractinians are incapable of genetic adaptation to rapid global changes, the alternative response would be phenotypic plasticity, which is classically described as acclimatization. With the purpose of establishing a baseline for the study of acclimatization in corals of the Pacific coast of Mexico, we assessed the molecular and physiological response of 36 colonies of 3 Pocillopora morphospecies (Pocillopora cf. capitata, Pocillopora cf. damicornis, and Pocillopora cf. verrucosa) located at 2 sites (east and west) on Carrizales Reef. Our results show higher incidence of light and chlorophyll concentrations in seawater samples from the west side, suggesting the presence of at least 2 microenvironments with more and less light in the reef. In response, coral morphospecies from the west side showed higher gene expression and significant differences in pigment concentrations, endosymbiont densities, and metabolic markers (RNA, DNA, and proteins). Given the present concern about the future of coral reefs, we consider that the present study could be used as a baseline for the study of the physiological and molecular plasticity of Pocillopora corals in Mexican waters, so conservation strategies could be developed for key morphospecies in coral reefs on the Pacific coast of Mexico.
\end{abstract}

Key words: phenotypic plasticity, acclimatization, molecular physiology, Symbiodiniaceae.

RESUMEN. Actualmente, la mayor amenaza que enfrentan los corales escleractinios es el cambio climático acelerado. Suponiendo que la mayoría de los escleractinios son incapaces de una respuesta de adaptación a los rápidos cambios globales, una respuesta alternativa sería la plasticidad fenotípica, que se describe clásicamente como aclimatación. Con el fin de establecer una línea base para el estudio de la aclimatación en los corales de la costa mexicana del Pacífico, en el presente trabajo evaluamos la plasticidad de la respuesta fisiológica y molecular de 36 colonias pertenecientes a 3 morfoespecies del género Pocillopora (Pocillopora cf. capitata, Pocillopora cf. damicornis y Pocillopora cf. verrucosa), ubicadas en 2 sitios (este y oeste) del arrecife Carrizales. Los datos ambientales revelaron mayor incidencia de luz y concentraciones más altas de clorofila en las muestras de agua del sitio oeste, lo que sugiere la presencia de al menos 2 microambientes con mayor y menor luz en el arrecife. Como respuesta, las morfoespecies del sitio oeste mostraron una mayor expresión génica y diferencias significativas en el contenido de pigmentos, la densidad de endosimbiontes y los marcadores metabólicos (ARN, ADN y proteínas). Dada la preocupación por el futuro de los arrecifes, consideramos que el presente estudio puede servir como línea base para el estudio de la plasticidad fisiológica y molecular de los corales Pocillopora de México, y con ello se podrán desarrollar estrategias de conservación para las morfoespecies clave en los arrecifes coralinos de la costa mexicana del Pacífico.

Palabras clave: plasticidad fenotípica, aclimatación, fisiología molecular, Symbiodiniaceae.

\section{INTRODUCTION}

The greatest threat to corals today is accelerated global climate change (GCC). GCC is mainly defined as the increase in the average temperature of the planet, due to the accelerated increase in atmospheric $\mathrm{CO}_{2}$, as a result of increasing anthropogenic activity since the post-industrial era (Hughes et al. 2017). Among other extreme changes caused by GCC, the increase in seawater temperature is the one that most affects the mutualistic relationship between corals and their

\section{INTRODUCCIÓN}

Actualmente, la mayor amenaza que enfrentan los corales es el acelerado cambio climático global (CCG). El CCG se define principalmente como el aumento en la temperatura promedio del planeta, debido al incremento acelerado del $\mathrm{CO}_{2}$ atmosférico, como resultado de la creciente actividad antropogénica desde la época posindustrial (Hughes et al. 2017). Entre otros cambios extremos que genera el CCG, el incremento en la temperatura del agua de mar es el que más 
endosymbiont dinoflagellates of the Symbiodiniaceae family (sensu LaJeunesse et al. 2018). Extreme and prolonged increases in seawater temperature cause the loss of the endosymbiotic relationship and, consequently, the bleaching of scleractinian corals. Bleaching can cause mass mortality in most species, resulting in reef degradation and worldwide environmental crisis (Eakin et al. 2019). Therefore, one of the main concerns is to understand the capacity of corals to acclimatize to environmental conditions (phenotypic plasticity) and to cope with GCC (Palumbi et al. 2014, Barshis 2015). Laboratory and field experiments that help elucidate the acclimatization capacity of scleractinian corals are thus of great relevance.

The acclimatization capacity of Pocillopora corals is of particular interest, largely because their phenotypic plasticity is extremely high. Nevertheless, the effects of high plasticity on the main cellular stress response pathways have been scarcely studied. Considering all the above, we examined the messenger RNA (mRNA) expression profiles for the morphospecies Pocillopora cf. capitata, Pocillopora cf. damicornis, and Pocillopora cf. verrucosa, which are the most abundant morphospecies at Carrizales Reef, off the coast of Colima, Mexico. Using quantitative PCR (Mayfield et al. 2013a, 2013b) and Pocillopora transcriptome sequencing (Mayfield et al. 2014a, 2014b) techniques, we evaluated the expression levels of carbonic anhydrase (CA) mRNA, copper,zinc-superoxide dismutase (CuZnSOD), green fluorescent protein-like chromoprotein (GFP-like cp), and 70-kDa heat shock protein (HSP70). In addition, we evaluated the ratios of nucleic acids and proteins, the content of pigments and mycosporine-like amino acids, and the densities of endosymbionts in coral tissues because these indicators have proven useful for assessing coral physiology and health (Hinrichs et al. 2013). To date, our results are the first to reveal the plasticity of gene expression in Pocillopora morphospecies from Carrizales Reef. We conclude that these results can be used as baseline elements for the study of acclimatization in the different Pocillopora morphospecies on the Pacific coast of Mexico.

\section{MATERIALS AND METHODS}

\section{Study site and sample collection}

Carrizales Reef is located in Carrizales Bay $\left(19^{\circ} 05^{\prime} 42^{\prime \prime} \mathrm{N}\right.$, $104^{\circ} 26^{\prime} 21^{\prime \prime}$ W), just southwest of the coast of Manzanillo, Colima, Mexico (Fig. 1). On 13 February 2017, an expedition to Carrizales Reef was carried out using autonomous diving equipment, during which a total of 36 fragments of the corals $P$. cf. capitata, $P$. cf. damicornis, and $P$. cf. verrucosa were collected from 12 colonies on the east and west margins of the reef $(n=6)$. To reduce the effects of environmental variation, colonies that were sympatrically distributed at $3 \mathrm{~m}$ depth were selected. Each colony was identified by the typical morphological characteristics (following Veron afecta la relación mutualista entre los corales y sus dinoflagelados endosimbiontes de la familia Symbiodiniaceae (sensu LaJeunesse et al. 2018). Los incrementos extremos y prolongados en la temperatura del agua de mar ocasionan la pérdida de la relación endosimbionte y, como consecuencia, el blanqueamiento de los corales escleractinios. El blanqueamiento puede causar una mortalidad masiva en la mayoría de las especies, lo que resulta en la degradación de los arrecifes y ocasiona una crisis ambiental global (Eakin et al. 2019). Por lo tanto, una de las principales preocupaciones es conocer las capacidades de aclimatación ambiental (plasticidad fenotípica) de los corales para hacer frente al CCG (Palumbi et al. 2014, Barshis 2015). En este sentido, los experimentos de laboratorio y campo que permitan conocer mejor las capacidades de aclimatación en corales escleractinios son de gran relevancia.

Las capacidades de aclimatación en los corales Pocillopora presentan un interés particular, debido en gran medida a que su plasticidad fenotípica es extremadamente alta. No obstante, los efectos de la alta plasticidad en las principales rutas celulares de respuesta al estrés han sido poco estudiados. Con todo lo anterior en mente, investigamos los perfiles de expresión del ARN mensajero (ARNm) en las morfoespecies Pocillopora cf. capitata, Pocillopora cf. damicornis y Pocillopora cf. verrucosa, que son las más abundantes en el arrecife Carrizales de la costa de Colima, México. Basándonos en estudios de PCR cuantitativa (Mayfield et al. 2013a, 2013b) y de secuenciación del transcriptoma de Pocillopora (Mayfield et al. 2014a, 2014b), evaluamos los niveles de expresión del ARNm de anhidrasa carbónica (AC), superóxido dismutasa con cobre y zinc (CuZnSOD), cromoproteína similar a la proteína verde fluorescente (cp tipo GFP) y proteína de choque térmico de $70 \mathrm{kDa}$ (HSP70). Así mismo, evaluamos las razones de ácidos nucleicos y proteínas, el contenido de pigmentos y aminoácidos tipo micosporina, y las densidades de endosimbiontes en los tejidos del coral, ya que estos indicadores han demostrado ser útiles para evaluar la condición fisiológica y de salud en corales (Hinrichs et al. 2013). Hasta el momento, nuestros resultados son los primeros en mostrar la plasticidad de la expresión génica en morfoespecies de Pocillopora procedentes del arrecife Carrizales. Concluimos que estos resultados pueden ser utilizados como elementos de línea base para el estudio de la aclimatación de las distintas morfoespecies de Pocillopora en la costa mexicana del Pacífico.

\section{MATERIALES Y MÉTODOS}

\section{Sitio de estudio y recolección de muestras}

El arrecife Carrizales se localiza en la bahía de Carrizales $\left(19^{\circ} 05^{\prime} 42^{\prime \prime} \mathrm{N}, 104^{\circ} 26^{\prime} 21^{\prime \prime} \mathrm{W}\right)$, ubicada al suroeste de la costa de Manzanillo, Colima, México (Fig. 1). El 13 de febrero de 2017 se realizó una expedición al arrecife Carrizales utilizando equipo de buceo autónomo, durante la cual 


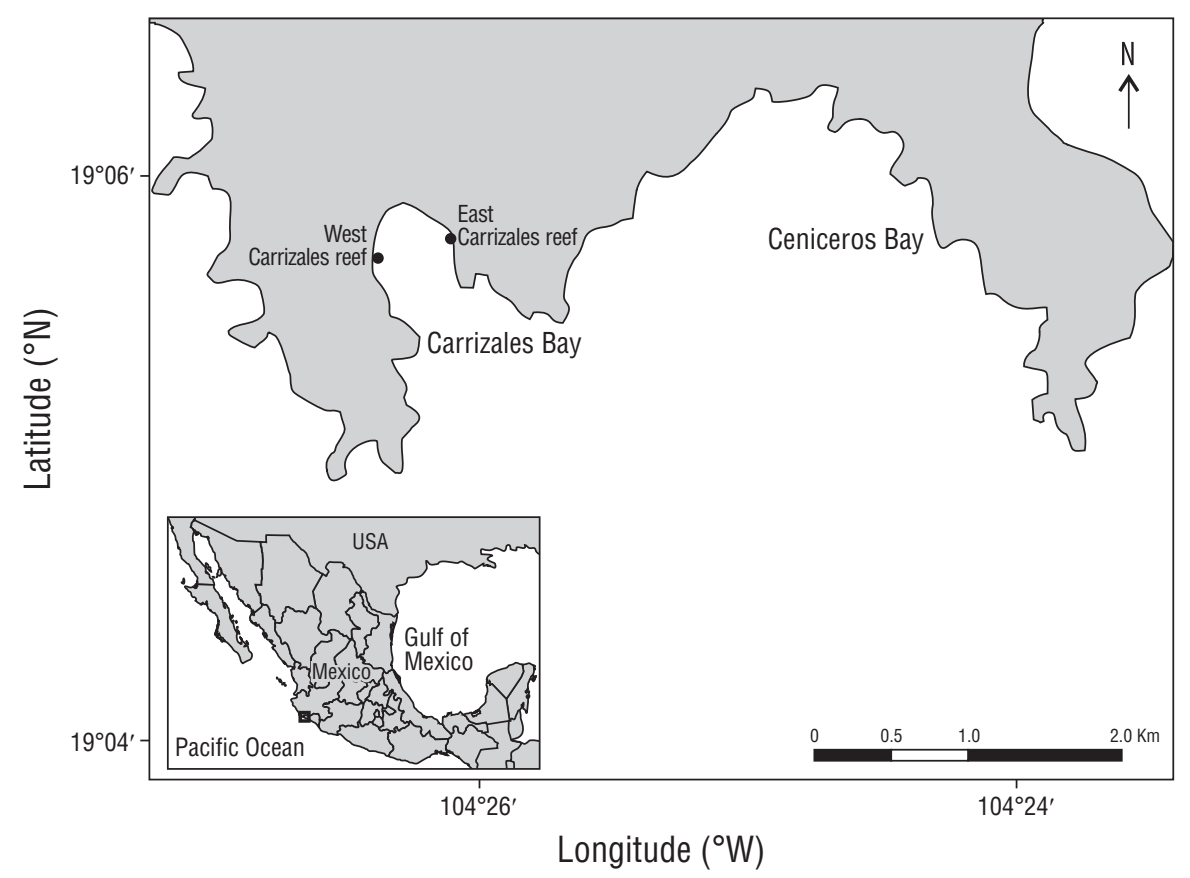

Figure 1. Location of Carrizales Reef on the coast of Colima, Mexico.

Figura 1. Ubicación del arrecife Carrizales en la costa de Colima, México.

2000). However, since colony morphology is generally incongruous with genetics (Pinzón and LaJeunesse 2011), there is a possibility that the colonies belong to homogeneous genetic groups.

After the expedition, biological samples were divided into 3 groups of 12 fragments, which were immediately processed in the field and protected from light during transportation. Two of the groups were separately preserved in plastic vials, one with $10 \mathrm{~mL}$ of $10 \%$ formaldehyde and the other with $10 \mathrm{~mL}$ of cold RNAlater solution. Afterwards, samples in formaldehyde were refrigerated and samples in RNAlater were frozen at $-80{ }^{\circ} \mathrm{C}$ until laboratory analysis. The remaining group of samples were initially transferred into microtubes with $2 \mathrm{~mL}$ of $100 \%$ methanol, subsequently stored at $4{ }^{\circ} \mathrm{C}$ for $24 \mathrm{~h}$ in total darkness, and lastly analyzed in the laboratory.

In addition, 6 samples of $1.0 \mathrm{~L}$ of seawater were collected at $1.0 \mathrm{~m}$ depth at each reef sampling site (east and west), at approximately 1-h intervals throughout the sampling duration $(\sim 4 \mathrm{~h})$. Chlorophyll $a(\mathrm{Chla})$ concentration in these samples was determined with a Jenway 6500 spectrophotometer (Chelmsford, Essex, UK), according to the methodologies of Strickland and Parsons (1972) and Grasshoff et al. (1999). The results are shown as Chla concentration per volume of seawater $\left(\mathrm{mg} \cdot \mathrm{m}^{-3}\right)$. Owing to the technical difficulties in continuously recording light and temperature data during the expedition on 13 February, a second expedition was conducted on 27 May 2017 to obtain a new log. To do this, Onset HOBO Pendant UA-002-08 sensors (Onset Computer Corporation; se recolectaron un total de 36 fragmentos de los corales $P$. cf. capitata, P. cf. damicornis y P. cf. verrucosa de 12 colonias provenientes de los márgenes este y oeste del arrecife $(n=6)$. Para reducir los efectos de la variación ambiental, se seleccionaron colonias distribuidas simpátricamente a $3 \mathrm{~m}$ de profundidad. Cada colonia se identificó mediante características morfológicas clásicas (después de Veron 2000). Sin embargo, ya que la morfología de las colonias generalmente es incongruente con la genética (Pinzón y LaJeunesse 2011), existe la posibilidad de que las colonias pertenecieran a grupos genéticos homogéneos.

Una vez concluida la expedición, las muestras biológicas se separaron en 3 grupos de 12 fragmentos, que se procesaron inmediatamente en campo y se protegieron de la luz durante el transporte. Dos de los grupos se preservaron por separado en viales de plástico, uno con $10 \mathrm{~mL}$ de formaldehído al 10\% y el otro con $10 \mathrm{~mL}$ de solución RNAlater en frío. Posteriormente, las muestras en formaldehído se refrigeraron y las muestras en RNAlater se congelaron a $-80{ }^{\circ} \mathrm{C}$ hasta el momento del análisis en laboratorio. El grupo restante de muestras fue transferido a microtubos con $2 \mathrm{~mL}$ de metanol al $100 \%$, posteriormente almacenado a $4^{\circ} \mathrm{C}$ por $24 \mathrm{~h}$ en total oscuridad y finalmente analizado en laboratorio.

Adicionalmente, se recolectaron 6 muestras de $1.0 \mathrm{~L}$ de agua de mar a $1.0 \mathrm{~m}$ de profundidad en cada sitio de muestreo del arrecife (este y oeste), en intervalos aproximados de $1 \mathrm{~h}$ durante el tiempo en que transcurrió el muestreo $(\sim 4 \mathrm{~h})$. La concentración de clorofila $a(\mathrm{Cl} a)$ en estas muestras se determinó con un espectrofotómetro Jenway 6500 (Chelmsford, 
Bourne, MA, USA) were used. Prior bi-monthly monitoring showed that seasonal variability in the reef occurs every 4 months (Muñiz-Aguiano et al. 2017). So even though these data do not correspond to the conditions on 13 February, we believe the values obtained on 27 May do allow for a reliable comparison of the spatial variation between the east and west sides of Carrizales Reef.

\section{Laboratory analysis}

The density of endosymbiont dinoflagellates was quantified from the fragments in formaldehyde by employing a modification to the protocol proposed by Zamoum and Furla (2012). Briefly, coral tissue was removed from the skeleton by incubation in $10 \mathrm{~mL}$ of $4 \mathrm{M} \mathrm{NaOH}$ at $65.0^{\circ} \mathrm{C}$ for $1 \mathrm{~h}$. The homogenate was then kept overnight at $37.5^{\circ} \mathrm{C}$ and Symbiodiniaceae cell density was later quantified from a $10-\mu \mathrm{L}$ aliquot using a Neubauer hemocytometer $(n=8$ replicates).

Pigment concentration was determined from the fragments that were preserved in $100 \%$ methanol at $4.0^{\circ} \mathrm{C}$. After storing for $24 \mathrm{~h}$, the homogenate was sonicated for $15 \mathrm{~s}$ and then centrifuged at $1,500 \times g$ for $5 \mathrm{~min}$ at $4^{\circ} \mathrm{C}$; the resulting extracts were protected from the light and immediately used to measure absorbance by scanning wavelengths from 300 to $750 \mathrm{~nm}$ every $1 \mathrm{~nm}$. Duplicate measurements were performed in a Spectronic Genesys 5 spectrophotometer (Thermo Fisher Scientific; Waltham, MA, USA) using 96-well microplates. Pigment content was calculated from the extinction coefficients for the $\beta$-carotene $\left(145.0 \mathrm{~L} \cdot \mathrm{g}^{-1} \cdot \mathrm{cm}^{-1}\right)$ and perinidine $\left(132.5 \mathrm{~L} \cdot \mathrm{g}^{-1} \cdot \mathrm{cm}^{-1}\right.$ ) carotenoids (Jeffrey and Haxo 1968) and for the diadinoxanthin $\left(223.0 \mathrm{~L} \cdot \mathrm{g}^{-1} \cdot \mathrm{cm}^{-1}\right)$ and dinoxanthin (135.0 L $\cdot \mathrm{g}^{-1} \cdot \mathrm{cm}^{-1}$ ) xanthophylls (Vernon 1960), and total chlorophyll concentration (Chla and Chlc) was calculated according to the equations by Jeffrey and Humphrey (1975), with the recommended turbidity correction.

Nucleic acids and total proteins were extracted from the fragments in RNAlater after thawing. First, RNAlater excess was removed with a Kimwipes tissue (Kimberly-Clark; Roswell, GA, EUA). Then, samples were ground in a mortar, and approximately $100 \mathrm{mg}$ of tissue and skeleton were transferred into $1.5-\mathrm{mL}$ microcentrifuge tubes with $1.0 \mathrm{~mL}$ of TRIzol reagent (Life Technologies); samples were then homogenized using a mechanical disruptor (FastPrep24, MP Biomedicals; Santa Ana, CA, USA). The extractions were made following the specifications of the manufacturer with the following modifications. Briefly, up to $2 \mu \mathrm{L}$ of $6 \mathrm{M} \mathrm{HCl}$ were added to the homogenate to prevent the neutralization reaction that occurs between the calcium carbonate in the skeleton and the acidic TRIzol (Anderson et al. 2016). RNA was precipitated by adding isopropanol and incubating overnight at $-20^{\circ} \mathrm{C}$, and the solution was then centrifuged to precipitate the RNA, which was eluted in $50 \mu \mathrm{L}$ of ribonuclease-free water (RNase). DNA was recovered from the rest of the phenol solution following the recommendations
Essex, UK), de acuerdo con las metodologías de Strickland y Parsons (1972) y Grasshoff et al. (1999). Los resultados se muestran como la concentración de Cla por volumen de agua de mar $\left(\mathrm{mg} \cdot \mathrm{m}^{-3}\right)$. Debido a dificultades técnicas en el registro continuo de luz y temperatura durante la expedición del 13 de febrero, se realizó una segunda expedición el 27 de mayo de 2017 para obtener un nuevo registro. Para ello, se utilizaron sensores Onset HOBO Pendant UA-002-08 (Onset Computer Corporation; Bourne, MA, EUA). Mediante un monitoreo bimensual previo, se observó que la variabilidad estacional en el arrecife ocurre cada 4 meses (Muñiz-Aguiano et al. 2017). Por lo tanto, consideramos que si bien los datos no corresponden a las condiciones del 13 de febrero, los valores obtenidos el 27 de mayo permiten una comparación fiable de la variación espacial entre los sitios este y oeste del arrecife Carrizales.

\section{Análisis de laboratorio}

La densidad de dinoflagelados endosimbiontes se cuantificó a partir de los fragmentos preservados en formaldehído empleando una modificación del protocolo propuesto por Zamoum y Furla (2012). Brevemente, el tejido de coral fue removido del esqueleto mediante incubación en $10 \mathrm{~mL}$ de $\mathrm{NaOH} 4 \mathrm{M}$ a $65.0^{\circ} \mathrm{C}$ por $1 \mathrm{~h}$. Posteriormente, el homogeneizado se mantuvo a $37.5^{\circ} \mathrm{C}$ durante toda la noche, después de lo cual la densidad celular de Symbiodiniaceae se cuantificó a partir de una alícuota de $10 \mu \mathrm{L}$ utilizando un hematocitómetro Neubauer ( $n=8$ repeticiones).

La concentración de pigmentos se determinó a partir de los fragmentos preservados en $100 \%$ de metanol a $4.0^{\circ} \mathrm{C}$. Una vez transcurridas las $24 \mathrm{~h}$ de almacenamiento, el homogeneizado se sonicó durante $15 \mathrm{~s}$ y posteriormente se centrifugó a $1,500 \times g$ durante 5 min a $4{ }^{\circ} \mathrm{C}$; los extractos resultantes se protegieron de la luz y se utilizaron inmediatamente para la medición de las absorbancias, mediante el escaneado de las longitudes de onda de 300 a $750 \mathrm{~nm}$ cada $1 \mathrm{~nm}$. Las mediciones se realizaron por duplicado en un espectrofotómetro Spectronic Genesys 5 (Thermo Fisher Scientific; Waltham, MA, EUA) utilizando microplacas de 96 pozos. El contenido de pigmentos se calculó a partir de los coeficientes de extinción para los carotenoides $\beta$-caroteno $\left(145.0 \mathrm{~L} \cdot \mathrm{g}^{-1} \cdot \mathrm{cm}^{-1}\right)$ y perinidina $\left(132.5 \cdot \mathrm{L} \mathrm{g}^{-1} \cdot \mathrm{cm}^{-1}\right)$ (Jeffrey y Haxo 1968$)$ y para las xantofilas diadinoxantina $\left(223.0 \mathrm{~L} \cdot \mathrm{g}^{-1} \cdot \mathrm{cm}^{-1}\right)$ y dinoxantina $\left(135.0 \mathrm{~L} \cdot \mathrm{g}^{-1} \cdot \mathrm{cm}^{-1}\right)$ (Vernon 1960), y la concentración de clorofila total (Cla y Clc) se calculó de acuerdo con las ecuaciones de Jeffrey y Humphrey (1975), con la corrección de turbidez recomendada.

Los ácidos nucleicos y las proteínas totales se extrajeron a partir de los fragmentos en RNAlater una vez descongelados. Primero, se eliminó el exceso de RNAlater con un paño Kimwipes (Kimberly-Clark; Roswell, GA, EUA). Después, las muestras se trituraron en un mortero, y se transfirieron aproximadamente $100 \mathrm{mg}$ de tejido y esqueleto a tubos de microcentrífuga de $1.5 \mathrm{~mL}$ con $1.0 \mathrm{~mL}$ de reactivo TRIzol 
by Mayfield et al. (2012). Briefly, a back extraction buffer (4M guanidine thiocyanate, $50 \mathrm{mM}$ sodium citrate, and $1 \mathrm{M}$ Tris free base) was used. Equal volumes of back extraction buffer and phenol solution were mixed, and the mixture was subsequently centrifuged to obtain an aqueous phase, which was transferred into a new tube. DNA was precipitated and eluted in $200 \mu \mathrm{L}$ deoxyribonuclease-free water (DNase), with an additional 10 -min incubation at $55^{\circ} \mathrm{C}$. Lastly, proteins were precipitated from the remaining phenol solution by modifying the time of incubation and final solubilization $\left(40 \mathrm{~min}\right.$ at $50{ }^{\circ} \mathrm{C}$ in $\left.1 \% \mathrm{SDS}\right)$. The quantity and quality of nucleic acids and proteins were analyzed in a Nanodrop spectrophotometer and the samples were stored at $-80{ }^{\circ} \mathrm{C}$.

For the gene expression analysis, all RNA samples were thawed and purified by treatment with DNase I enzyme (without RNase) following the specifications of the manufacturer (Invitrogen, Thermo Fisher Scientific). With the purified RNA, 300 ng were reverse transcribed to the first strand of complementary DNA (cDNA) using the high-capacity reverse transcription kit and following the recommendations of the manufacturer (Applied Biosystems, Life Technologies; CA, USA). Aliquots of $20 \mathrm{ng} \cdot \mu \mathrm{L}^{-1}$ of cDNA were prepared and then stored at $-20^{\circ} \mathrm{C}$.

Relative mRNA expression was done by amplifying target genes (CA, CuZnSOD, GFP-like cp, and HSP70) and an internal control fragment (18 ribosomal RNA) to calibrate the complementary DNA template (Table 1). Eight independent real-time quantitative PCR (q-PCR) assays were performed, in a total volume of $20.0 \mu \mathrm{L}$ with $6.3 \mu \mathrm{L}$ of $2 \mathrm{X}$ SYBR Green Master Mix (Applied Biosystems), $0.6 \mu \mathrm{L}$ of each primer for the target gene and the internal control gene $\left(10 \mathrm{mmol} \cdot \mu \mathrm{L}^{-1}\right), 5.0 \mu \mathrm{L}$ of the cDNA sample $\left(20 \mathrm{ng} \cdot \mu \mathrm{L}^{-1}\right)$, and $6.9 \mu \mathrm{L}$ of RNase/DNase-free water. Q-PCR assays were carried out in a StepOnePlus thermocycler (Applied Biosystems) with the following thermocycling conditions: (1) "hot start" at $95^{\circ} \mathrm{C}$ for $10 \mathrm{~min}$, (2) amplification of 40 cycles at $95^{\circ} \mathrm{C}$ for $15 \mathrm{~s}$ followed by $60 \mathrm{~s}$ at $60^{\circ} \mathrm{C}$, and (3) fusion at $95^{\circ} \mathrm{C}$ for $15 \mathrm{~s}$ followed by $60 \mathrm{~s}$ at $60^{\circ} \mathrm{C}$ and $15 \mathrm{~s}$ at $95{ }^{\circ} \mathrm{C}$. Results are given in terms of relative mRNA expression as calculated with the $2^{-\Delta \Delta C t}$ method (Schmittgen and Livak 2008).

\section{Statistical analysis}

Statistical analyses were performed using $\mathrm{R}$ software. All data were analyzed with the Shapiro-Wilk normality test and the Bartlett test to determine homoscedasticity (95\% confidence intervals). For the environmental parameters, an unpaired 2-sample $t$-test was used. For biological parameters, 2-way analysis of variance (ANOVA) was used, followed by multiple comparisons (Tukey's test) to assess significant differences $(P<0.05)$. In some cases, the bidirectional non-parametric Friedman test and the paired sign test were used. All data were presented as mean values \pm standard error of the mean $(n=6)$.
(Life Technologies); posteriormente, se homogeneizaron usando un disruptor mecánico (FastPrep24, MP Biomedicals; Santa Ana, CA, EUA). Las extracciones se realizaron siguiendo las especificaciones del fabricante con las siguientes modificaciones. Brevemente, se agregaron hasta $2 \mu \mathrm{L}$ de $\mathrm{HCl} 6 \mathrm{M}$ al homogeneizado para evitar la reacción de neutralización que ocurre entre el carbonato de calcio del esqueleto y la acidez del TRIzol (Anderson et al. 2016). El ARN se precipitó mediante la adición de isopropanol e incubación a $-20{ }^{\circ} \mathrm{C}$ durante toda la noche, y posteriormente la solución se centrifugó para precipitar el ARN, el cual se eluyó en $50 \mu \mathrm{L}$ de agua libre de ribonucleasas (RNasas). El ADN se recuperó a partir del resto de la solución de fenol siguiendo las recomendaciones de Mayfield et al. (2012). Brevemente, se utilizó un tampón de retro-extracción (tiocinato de guanidina $4 \mathrm{M}$, citrato de sodio $50 \mathrm{mM}$ y Tris libre de base $1 \mathrm{M}$ ). Se mezclaron volúmenes iguales del tampón de retro-extracción y la solución de fenol, y posteriormente la mezcla se centrifugó para obtener una fase acuosa, la cual se transfirió a un tubo nuevo. El ADN se precipitó y se eluyó en $200 \mu \mathrm{L}$ de agua libre de desoxirribonucleasas (DNasas), con una incubación adicional de $10 \mathrm{~min}$ a $55^{\circ} \mathrm{C}$. Por último, las proteínas se precipitaron a partir de la solución de fenol restante con una modificación en el tiempo de incubación y solubilización final $\left(40 \mathrm{~min}\right.$ a $50^{\circ} \mathrm{C}$ en SDS al $\left.1 \%\right)$. La cantidad y la calidad de ácidos nucleicos y proteínas se analizaron en un espectrofotómetro Nanodrop y las muestras se almacenaron a $-80{ }^{\circ} \mathrm{C}$.

Para el análisis de expresión génica, todas las muestras de ARN se descongelaron y se purificaron mediante un tratamiento con la enzima DNasa I (sin ARNasa) siguiendo las especificaciones del fabricante (Invitrogen, Thermo Fisher Scientific). A partir del ARN purificado, se retro-transcribieron $300 \mathrm{ng}$ a ADN complementario (ADNc) de la primera cadena utilizando el kit de transcripción inversa de alta capacidad y siguiendo las recomendaciones del fabricante (Applied Biosystems, Life Technologies; CA, EUA). Se prepararon alícuotas de $20 \mathrm{ng} \cdot \mu \mathrm{L}^{-1}$ de $\mathrm{ADNc}$ y se almacenaron a $-20{ }^{\circ} \mathrm{C}$.

La expresión relativa del ARNm se llevó a cabo mediante la amplificación de los genes objetivo (AC, CuZnSOD, cp tipo GFP y HSP70) y un fragmento de control interno (18 ARN ribosomal) para calibrar el molde de ADN complementario (Tabla 1). Se realizaron 8 ensayos independientes de PCR cuantitativa en tiempo real (q-PCR), en un volumen total de $20.0 \mu \mathrm{L}$ con $6.3 \mu \mathrm{L}$ de $2 \mathrm{X}$ SYBR Green Master Mix (Applied Biosystems), $0.6 \mu \mathrm{L}$ de cada cebador del gen objetivo y el gen de control interno $\left(10 \mathrm{mmol} \cdot \mu \mathrm{L}^{-1}\right), 5.0 \mu \mathrm{L}$ de la muestra de ADNc $\left(20 \mathrm{ng} \cdot \mu \mathrm{L}^{-1}\right)$ y $6.9 \mu \mathrm{L}$ de agua libre de RNasa/DNasa. Los ensayos de q-PCR se llevaron a cabo en un termociclador StepOnePlus (Applied Biosystems) con las siguientes condiciones de termociclado: (1) inicio en caliente a $95^{\circ} \mathrm{C}$ por $10 \mathrm{~min}$, (2) amplificación de 40 ciclos a $95{ }^{\circ} \mathrm{C}$ por $15 \mathrm{~s}$ seguido de $60 \mathrm{~s}$ a $60^{\circ} \mathrm{C}$ y (3) fusión a $95^{\circ} \mathrm{C}$ por $15 \mathrm{~s}$, seguido de $60 \mathrm{~s}$ a $60{ }^{\circ} \mathrm{C}$ y $15 \mathrm{~s}$ a $95{ }^{\circ} \mathrm{C}$. Los resultados se expresan en términos de expresión relativa de ARNm calculada mediante el método $2^{-\Delta \Delta C t}$ (Schmittgen y Livak 2008). 
Table 1. Parameters for the primers used in the real-time quantitative PCR assays.

Tabla 1. Parámetros de los cebadores empleados en los ensayos de la PCR cuantitativa en tiempo real.

\begin{tabular}{|c|c|c|c|c|}
\hline $\mathrm{CA}$ & & R: ATAGCAGGGAGGGGTGGTAA & & \\
\hline $\mathrm{CuZnSOD}$ & & R: TCTTGCATGTGTCTCCCAC & & \\
\hline GFP-like cp & Light absorption & F: AGGCAAACAAACGGGGACATT & 60 & Mayfield et al. (2014b) \\
\hline \multirow[t]{2}{*}{ HSP70 } & Stress response & F: ATCCAGGCAGCGGTCTTGT & 60 & Mayfield et al. (2014b) \\
\hline & & R: TCGAGCAGCAGGATATCACTGA & & \\
\hline \multirow[t]{2}{*}{$18 \mathrm{~S}$} & Internal control & F: GCTAAATCCAAAATCCAACAGAG & 60 & This study \\
\hline & & R: TTGAATGTCTTTCATTCTAGTATTCAA & & \\
\hline
\end{tabular}

$\mathrm{T}_{\mathrm{m}}$ : melting temperature.

F: forward primer.

$\mathrm{R}$ : Reverse primer.

\section{RESULTS}

The expression of CA in $P$. cf. capitata was higher in the western $(P<0.05)$ than in the eastern reef colonies (Fig. 2). The GFP-like cp expression was higher in the $P$. cf. verrucosa colonies from the west side $(P<0.05)$ than in the colonies from the east side (Fig. 3). On the other hand, the CuZnSOD expression in $P$. cf. capitata was also higher in the western colonies $(P<0.05)$ compared to eastern reef colonies. Contrary to CA and GFP-like cp expressions, the expression of the CuZnSOD enzyme was lower in the $P$. cf. verrucosa colonies $(P<0.05)$ in relation to the $P$. cf. capitata colonies (Fig. 4). Finally, the HSP70 expression did not show significant differences between the east and the west; nevertheless, all mean values of the HSP70 expression were consistently higher in western corals (Fig. 5).

In the joint analysis of Chla and Chlc, carotenoids, xanthophylls, endosymbiont density, mycosporine-like amino acids, and the RNA/DNA, protein/DNA, and RNA/ protein ratios, significant differences were observed in the colonies of $P$. cf. capitata and $P$. cf. verrucosa from the east and west sides of the reef, whereas in the $P$. cf. damicornis colonies no significant differences were observed in any marker (Table 2). The environmental values for the Carrizales Reef area showed Chla concentrations of $0.18-0.99 \mathrm{mg} \cdot \mathrm{m}^{-3}$ throughout the sampling. The highest values occurred on the west side of the reef $\left(0.99 \pm 0.17 \mathrm{mg} \cdot \mathrm{m}^{-3}\right)$ compared to the east side $(0.42 \pm$ $\left.0.10 \mathrm{mg} \cdot \mathrm{m}^{-3}\right)$. Finally, the light values that were recorded months after sampling at Carrizales Reef were higher for the west $\left(63.60 \pm 7.91 \mathrm{~W} \cdot \mathrm{m}^{-2} \cdot \mathrm{S}^{-1}\right)$ in comparison with the light values for the east $\left(44.42 \pm 5.26 \mathrm{~W} \cdot \mathrm{m}^{-2} \cdot \mathrm{S}^{-1}\right)$. On the other hand, temperature data were the same at both sites $\left(25 \pm 0.10^{\circ} \mathrm{C}\right)$.

\section{Análisis estadístico}

Los análisis estadísticos se realizaron utilizando el software R. Todos los datos se analizaron con la prueba de normalidad Shapiro-Wilk y la prueba de Bartlett para determinar la homocedasticidad (intervalos de confianza del 95\%). Para los parámetros ambientales, se utilizó una prueba $t$ de 2 muestras no apareada. Para los parámetros biológicos, se utilizó el análisis de varianza de 2 vías (ANDEVA), seguido de comparaciones múltiples (prueba de Tukey) para evaluar las diferencias significativas $(P<0.05)$. En algunos casos, se utilizó la prueba no paramétrica de Friedman bidireccional y la prueba de signos pareada. Todos los datos se presentaron como valores promedio \pm error estándar de la media $(n=6)$.

\section{RESUltados}

La expresión de la AC en $P$. cf. capitata fue mayor en las colonias del oeste $(P<0.05)$ que en las colonias del este del arrecife (Fig. 2). La expresión de la cp tipo GFP fue mayor en las colonias de $P$. cf. verrucosa del sitio oeste $(P<0.05)$ que en las colonias del sitio este (Fig. 3). Por otro lado, la expresión de la CuZnSOD en $P$. cf. capitata también fue mayor en las colonias del oeste $(P<0.05)$, en relación con las colonias del este del arrecife. A diferencia de la AC y la cp tipo GFP, la expresión de la enzima CuZnSOD fue menor en las colonias de $P$. cf. verrucosa $(P<0.05)$, en relación con las colonias de $P$. cf. capitata (Fig. 4). Finalmente, la expresión de la HSP70 no mostró diferencias significativas entre el este y el oeste; no obstante, todos los valores promedio de la expresión de la HSP70 fueron consistentemente mayores en los corales del oeste (Fig. 5). 


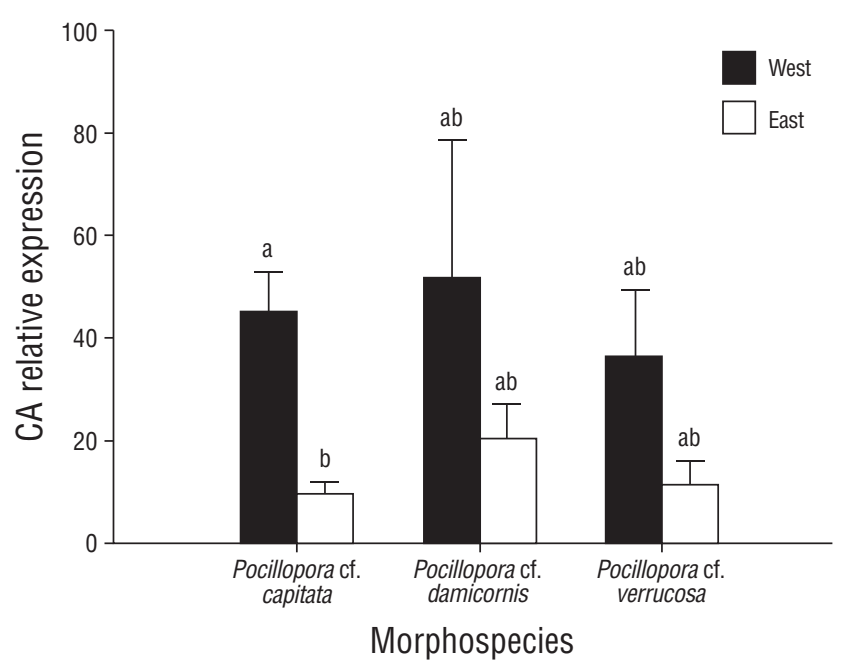

Figure 2. Expression levels of carbonic anhydrase (CA) mRNA in Pocillopora morphospecies on the east and west sides of Carrizales reef. Values are the mean \pm standard error of the mean $(n=6)$. Letters denote significant differences between the data $(P<0.05)$.

Figura 2. Niveles de expresión de ARNm de la anhidrasa carbónica (CA) en morfoespecies de Pocillopora del este y oeste del arrecife Carrizales. Se muestran los valores de la media \pm error estándar de la media $(n=6)$. Las letras denotan las diferencias significativas entre los datos $(P<0.05)$.

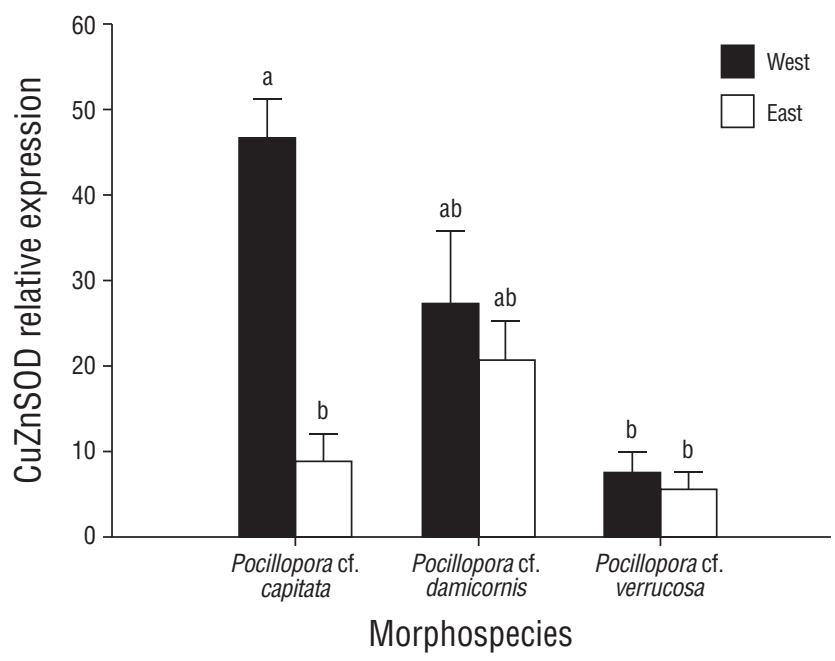

Figure 4. Expression levels of copper,zinc-superoxide dismutase (CuZnSOD) mRNA in Pocillopora morphospecies on the east and west sides of Carrizales reef. Values are the mean \pm standard error of the mean $(n=6)$. Letters denote significant differences between the data $(P<0.05)$.

Figura4. Valores de expresión del ARNm de superóxido dismutasa con cobre y zinc (CuZnSOD) en morfoespecies de Pocillopora del este y oeste del arrecife Carrizales. Se muestran los valores de la media \pm error estándar de la media $(n=6)$. Las letras denotan las diferencias significativas entre los datos $(P<0.05)$.

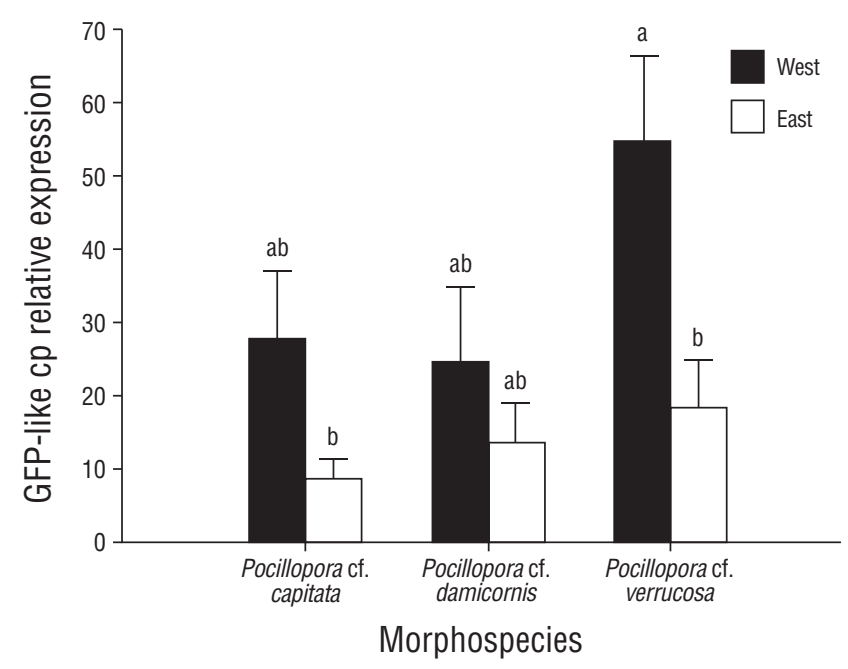

Figure 3. Expression levels of green fluorescent protein-like chromoprotein(GFP-like cp) mRNA in Pocillopora morphospecies on the east and west sides of Carrizales reef. Values are the mean \pm standard error of the mean $(n=6)$. Letters denote significant differences between the data $(P<0.05)$.

Figura 3. Niveles de expresión de ARNm de la cromoproteína similar a la proteína verde fluorescente (GFP-like $\mathrm{cp}$ ) en morfoespecies de Pocillopora del este y oeste del arrecife Carrizales. Se muestran los valores de la media \pm error estándar de la media $(n=6)$. Las letras denotan las diferencias significativas entre los datos $(P<0.05)$.

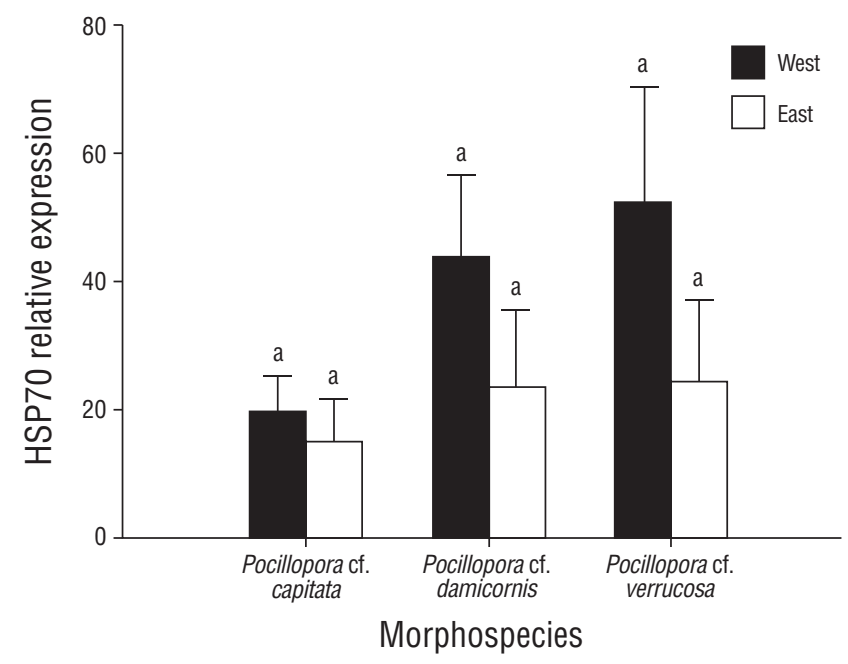

Figure 5. Expression levels of heat shock protein (HSP70) mRNA in Pocillopora morphospecies on the east and west sides of Carrizales reef. Values are the mean \pm standard error of the mean $(n=6)$. Letters denote significant differences between the data $(P<0.05)$.

Figura 5. Valores de expresión de ARNm de la proteína de choque térmico (HSP70) en morfoespecies de Pocillopora del arrecife Carrizales. Se muestran los valores de la media \pm error estándar de la media $(n=6)$. Las letras denotan las diferencias significativas entre los datos $(P<0.05)$. 


\section{Discussion}

The present study is the first approach to elucidate phenotypic plasticity, which was assessed through gene expression, in corals of the genus Pocillopora at Carrizales Reef. This plasticity in gene expression was observed in mainly the $P$. cf. capitata and $P$. cf. verrucosa morphospecies; however, the response of the 3 morphospecies (including $P$. cf. damicornis) was clearly associated with the sampling site at the reef.

The results mainly showed that the expression of CA and GFP-like cp was higher on the west side of the reef, where light and chlorophyll in seawater were also higher, compared to the east side. This suggests that CA and GFPlike cp are an important part of the acclimatization response of Pocillopora morphospecies, possibly because of variations in the light regime and the implications in regulating endosymbiont density, pigment concentration, and metabolic activity in coral tissue. This could be associated in the first instance to the fact that CAs are essential to provide bicarbonate to the calcification site and dissolved inorganic carbon for photosynthesis through the interconversion activity of $\mathrm{CO}_{2}$ and $\mathrm{HCO}^{3-}$ (Moya et al. 2008). Secondly, GFP-like cp has been found to possess a photoprotective function by absorbing and/or redistributing photons away from the absorption bands of photosynthetic pigments (Smith et al. 2013). Lastly, the amount of light corals receive is essential for adequate metabolic activity (Buckley and Szmant 2004) because corals depend on high-radiation environments, where solar energy is used by endosymbionts for photosynthesis and is part of the host metabolism (Iglesias-Prieto and Trench 1997, Bongaerts et al. 2011).

Considering, then, that the regulation of endosymbionts and their pigments is essential to maintain metabolic homeostasis (Iglesias-Prieto and Trench 1997, Bongaerts et al. 2011), the plasticity of the expression of CA and GFP-like $\mathrm{cp}$ is fundamental for coral photoacclimatization. This suggests that the amount of light received by coral colonies on the east and west margins of the reef is strongly associated with the high plasticity of gene expression, endosymbiont density, pigment concentration, and metabolic markers found in the morphospecies. Nevertheless, it is worth noting that the results of studies on other coral species contrast with the data of the present study. For example, in the Styllophora pistillata (Pocilloporidae) coral, the expression of a CA isoform has been observed to be higher in dark conditions (Moya et al. 2008). Furthermore, the photoprotection provided by chromoproteins occurs mainly when the hosts have low endosymbiont density (Smith et al. 2013). Lastly, chlorophyll concentrations and endosymbiont density increase in low light (Iglesias-Prieto and Trench 1997), and heterotrophic feeding can also affect RNA, DNA, and protein ratios (Buckley and Szmant 2004). Therefore, in the future, it
En el análisis conjunto de $\mathrm{Cla}$ y $\mathrm{Cl} c$, carotenoides, xantófilas, densidad de endosimbiontes, aminoácidos tipo micosporina y razones ARN/ADN, proteína/ADN y ARN/proteína se observaron diferencias significativas en las colonias de $P$. cf. capitata y $P$. cf. verrucosa del este y el oeste del arrecife, mientras que en las colonias de $P$. cf. damicornis no se observaron diferencias significativas en ningún marcador (Tabla 2). En relación con los valores ambientales, el arrecife de Carrizales presentó concentraciones de Cla de $0.18-0.99 \mathrm{mg} \cdot \mathrm{m}^{-3}$ a lo largo del muestreo. Los valores más altos ocurrieron en el sitio oeste del arrecife $\left(0.99 \pm 0.17 \mathrm{mg} \cdot \mathrm{m}^{-3}\right)$, en comparación con el sitio este $\left(0.42 \pm 0.10 \mathrm{mg} \cdot \mathrm{m}^{-3}\right)$. Por último, los datos de luz registrados meses después del muestreo en el arrecife Carrizales fueron mayores en el oeste $\left(63.60 \pm 7.91 \mathrm{~W} \cdot \mathrm{m}^{-2} \cdot \mathrm{S}^{-1}\right)$, en comparación con los valores de luz en el este (44.42 \pm $\left.5.26 \mathrm{~W} \cdot \mathrm{m}^{-2} \cdot \mathrm{S}^{-1}\right)$. Por otra parte, los datos de temperatura fueron los mismos en ambos sitios $\left(25 \pm 0.10^{\circ} \mathrm{C}\right)$.

\section{DisCusión}

El presente estudio representa una primera aproximación para entender la plasticidad fenotípica, valorada mediante la expresión génica, en corales del género Pocillopora del arrecife Carrizales. Esta plasticidad en la expresión génica se observó principalmente en las morfoespecies $P$. cf. capitata y $P$. cf. verrucosa; sin embargo, la respuesta de las 3 morfoespecies (incluida $P$. cf. damicornis) estuvo claramente asociada al sitio de muestreo en el arrecife.

Los resultados mostraron, principalmente, que la expresión de AC y cp tipo GFP fue mayor en el sitio oeste del arrecife, donde los registros de la luz y la clorofila en el agua de mar también fueron mayores, en comparación con el sitio este. Esto sugiere que la AC y la cp tipo GFP forman parte importante de la respuesta de aclimatación de las morfoespecies de Pocillopora, posiblemente asociada con las variaciones del régimen lumínico y sus implicaciones en la regulación de la densidad de endosimbiontes, la concentración de pigmentos y la actividad metabólica en el tejido coralino. Lo anterior pudiera estar relacionado, en primera instancia, a que las $\mathrm{AC}$ son indispensables para proporcionar bicarbonato al sitio de calcificación y carbono inorgánico disuelto para la fotosíntesis mediante su actividad de interconversión de $\mathrm{CO}_{2}$ y $\mathrm{HCO}^{3-}$ (Moya et al. 2008). En segundo lugar, se ha visto que las cp tipo GFP poseen una función fotoprotectora mediante la absorción de fotones y/o su redistribución lejos de las bandas de absorción de los pigmentos fotosintéticos (Smith et al. 2013). Por último, la cantidad de luz que reciben los corales es indispensable para una correcta actividad metabólica (Buckley y Szmant 2004), ya que los corales dependen de los ambientes de alta radiación, donde la energía solar es utilizada por los endosimbiontes para la fotosíntesis y forma parte del metabolismo del huésped (Iglesias-Prieto y Trench 1997, Bongaerts et al. 2011). 
Delgadillo-Nuño et al.: Gene expression plasticity in Pocillopora corals

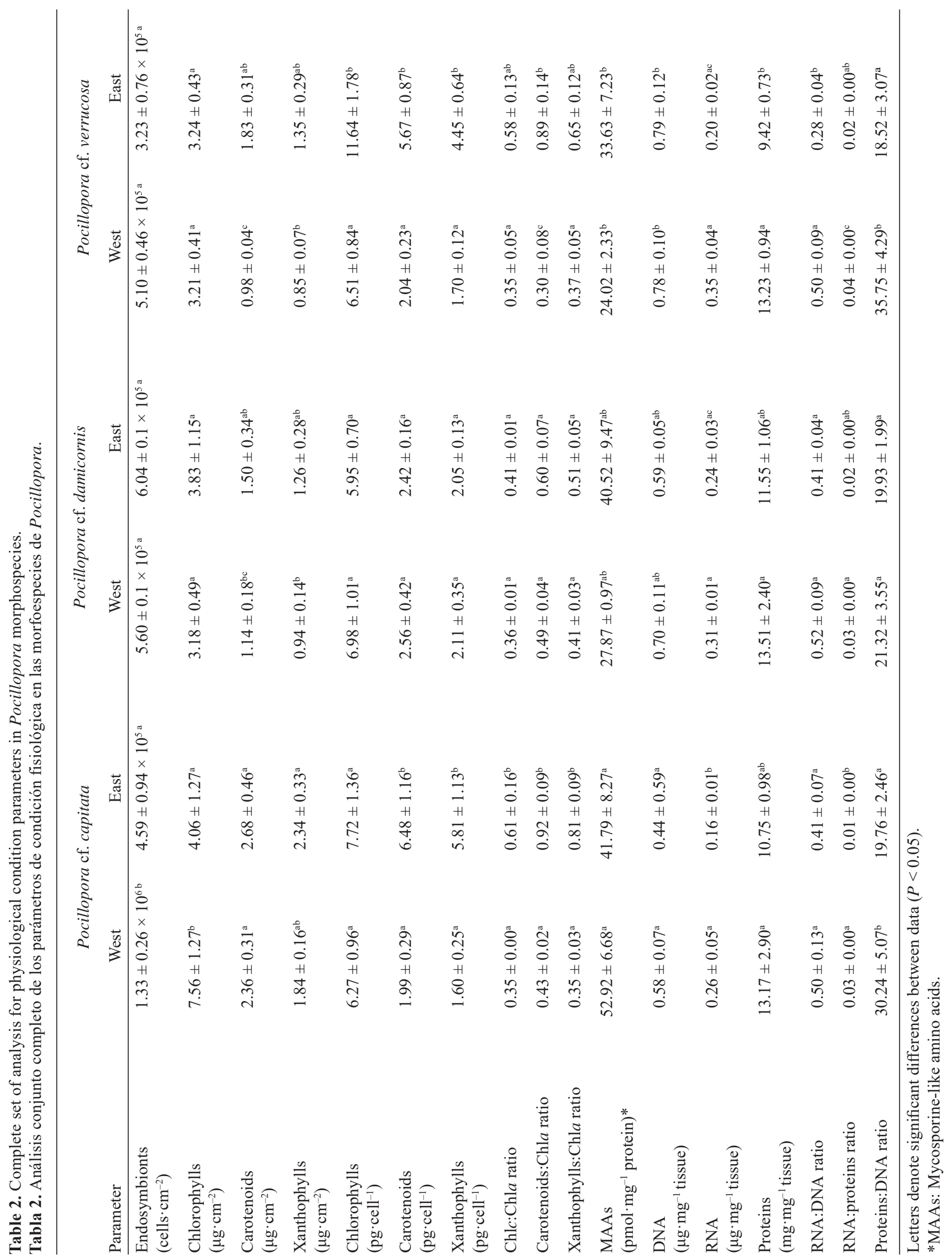


should be considered that the parameters of light incidence and penetration, water quality, food and nutrient availability, and the morphology and dynamics in Carrizales Bay are locally more variable than previously thought (e.g., Liñán-Cabello et al. 2011, Reyes-Bonilla et al. 2013, Muñiz-Anguiano et al. 2017).

In addition, our results showed high plasticity in the expression of 2 genes involved in stress response. The first is associated with the expression of CuZnSOD enzymes for preventing and controling sublethal levels of oxygen free radicals that cause oxidative stress (Mydlarz et al. 2016), and the second has to do with the expression of HSP70 chaperones that protect and help other proteins to regain their biological activity, mitigating the previously caused stress (Chiappori et al. 2016). Therefore, the high plasticity observed in both cell routes is also essential for the acclimatization of the Pocillopora morphospecies (Poli et al. 2017) at Carrizales Reef.

We conclude that our results can be used as a baseline for the study of physiological and molecular plasticity in Pocillopora corals on the Pacific coast of Mexico. Still, we believe that greater sampling effort would have enabled us to better elucidate the plasticity responses observed in the corals included in this study and the plasticity of the other 3 morphospecies not included here (Pocillopora cf. eydouxi, Pocillopora cf. inflate, and Pocillopora cf. meandrina). However, these morphospecies show low relative abundance at Carrizales Reef (Reyes-Bonilla et al. 2013). Furthermore, taking into account that Pocillopora corals on the Pacific coast of Mexico are of great importance for the local formation of reefs and show less calcification, as opposed to corals in other geographic regions of the world (Cabral-Tena et al. 2018), we believe that continuing to study these organisms, and to locally protect them, is essential to better understand the stress response of coral communities in this region under a scenario of worldwide changes in the ocean.

\section{ACKNOWLEDGMENTS}

This work was supported by the National Council of Science and Technology (CONACYT, Mexico) through the Basic Science-2012 project, no. 181597, for which EJCI was responsible. MADN received a doctoral scholarship (no. 486385) from CONACYT to carry out this study and appreciates the support provided. We thank all the students at the University of Colima who helped us during field sampling and, especially, Aramís Olivos-Ortíz with the Centro Universitario de Investigaciones Oceanológicas for her help in determining the chlorophyll of sea water. We thank Mariana Delgado-Fernández for her help in preparing the map of the study site.

English translation by Claudia Michel-Villalobos.
Considerando, entonces, que la regulación de los endosimbiontes y sus pigmentos es esencial para mantener la homeostasis metabólica (Iglesias-Prieto y Trench 1997, Bongaerts et al. 2011), la plasticidad de la expresión de AC y cp tipo GFP es fundamental para la fotoaclimatación de los corales. Esto sugiere una estrecha asociación entre la cantidad de luz que reciben las colonias de coral en el este y el oeste del arrecife y la alta plasticidad de la expresión génica, la densidad de endosimbiontes, la concentración de pigmentos y los marcadores metabólicos que muestran las morfoespecies. No obstante, es importante considerar que estudios con otras especies de corales contrastan con los datos del presente estudio. Por ejemplo, en el coral Styllophora pistillata (Pocilloporidae), se ha visto que una isoforma de la AC se expresa más en condiciones de oscuridad (Moya et al. 2008). Además, la fotoprotección que ofrecen las cromoproteínas ocurre principalmente cuando los hospederos cuentan con una baja densidad de endosimbiontes (Smith et al. 2013). Por último, las concentraciones de clorofila y la densidad de endosimbiontes aumentan cuando hay poca luz (Iglesias-Prieto y Trench 1997), y la alimentación heterotrófica también puede afectar las relaciones de ARN, ADN y proteínas (Buckley y Szmant 2004). Por lo tanto, en el futuro debería considerarse que los parámetros incidencia y penetración de la luz, calidad del agua, disponibilidad de alimento y nutrientes, y morfología y dinámica en la bahía de Carrizales son localmente más variables de lo que se había pensado hasta ahora (e.g., Liñán-Cabello et al. 2011, Reyes-Bonilla et al. 2013, Muñiz-Anguiano et al. 2017).

Adicionalmente, los resultados mostraron una alta plasticidad en la expresión de 2 genes de la respuesta al estrés. El primero tiene que ver con la expresión de enzimas CuZnSOD para prevenir y controlar los niveles subletales de radicales libres de oxígeno que provocan el estrés oxidativo (Mydlarz et al. 2016), y el segundo con la expresión de las chaperonas HSP70 que protegen y ayudan a otras proteínas a recuperar su actividad biológica, lo que mitiga el estrés previamente ocasionado (Chiappori et al. 2016). Por lo tanto, la alta plasticidad observada en ambas rutas celulares también es indispensable para la aclimatación de las morfoespecies de Pocillopora (Poli et al. 2017) en el arrecife Carrizales.

Concluimos que nuestros resultados pueden ser utilizados como una línea base para el estudio de la plasticidad fisiológica y molecular en los corales Pocillopora de la costa mexicana del Pacífico. No obstante, consideramos que un mayor esfuerzo de muestreo habría permitido elucidar mejor las respuestas de plasticidad observadas en los corales, así como la plasticidad de las 3 morfoespecies restantes que no se incluyeron en el estudio (Pocillopora cf. eydouxi, Pocillopora cf. inflata y Pocillopora cf. meandrina). Sin embargo, estas últimas morfoespecies presentan una baja abundancia relativa en el arrecife Carrizales (Reyes-Bonilla et al. 2013). Además, tomando en cuenta que los corales Pocillopora de la costa mexicana del Pacífico son de gran 


\section{REFERENCES}

Anderson DA, Walz ME, Weil E, Tonellato P, Smith MC. 2016. RNA-Seq of the Caribbean reef-building coral Orbicella faveolata (Scleractinia-Merulinidae) under bleaching and disease stress expands models of coral innate immunity. PeerJ. 4:e1616. https://oi.org/10.7717/peerj.1616

Barshis DJ. 2015. Genomic potential for coral survival of climate change. In: Birkeland C. (ed.), Coral Reefs in the Anthropocene. Dordrecht (Holland): Springer. p. 133-146. https://doi.org/10.1007/978-94-017-7249-5_7

Bongaerts P, Bridge TCL, Kline DI, Muir PR, Wallace CC, Beaman RJ, Hoegh-Guldberg O. 2011. Mesophotic coral ecosystems on the walls of coral sea atolls. Coral Reefs. 30(2):335. https://doi.org/10.1007/s00338-011-0725-7

Buckley BA, Szmant AM. 2004. RNA/DNA ratios as indicators of metabolic activity in four species of Caribbean reef-building corals. Mar Ecol Prog Ser. 282:143-149 (2004). https://doi.org/10.3354/meps282143

Cabral-Tena RA, López-Pérez A, Reyes-Bonilla H, CalderonAguilera LE, Norzagaray-López CO, Rodríguez-Zaragoza FA, Cupul-Magaña A, Rodríguez-Troncoso, AP Ayala-Bocos A. 2018. Calcification of coral assemblages in the eastern Pacific: Reshuffling calcification scenarios under climate change. Ecol Indic. 95(1):726-734. https://doi.org/10.1016/j.ecolind.2018.08.021

Chiappori F, Merelli I, Milanesi L, Colombo G, Morra G. 2016. An atomistic view of Hsp70 allosteric crosstalk: from the nucleotide to the substrate binding domain and back. Sci Rep-Uk. 6(1):23474. https://doi.org/10.1038/srep23474

Eakin CM, Sweatman HPA, Brainard RE. 2019. The 2014-2017 global-scale coralbleaching event: insights and impacts. Coral Reefs. 38(4):539-545. https://doi.org/10.1007/s00338-019-01844-2

Grasshoff K, Kremling K, Ehrhardt M. 1999. Methods of Seawater Analysis. 3rd ed. Weinheim (Germany): Verlag Chemie. 600 p.

Hinrichs S, Patten NL, Allcock RJN, Saunders SM, Strickland D, Waite AM. 2013. Seasonal variations in energy levels and metabolic processes of two dominant Acropora species (A. spicifera and A. digitifera) at Ningaloo Reef. Coral Reefs. 32(3):623-635. https://doi.org/10.1007/s00338-013-1027-z

Hughes TP, Barnes ML, Bellwood DR, Cinner JE, Cumming GS, Jackson JBC, Kleypas J, van de Leemput IA, Lough JM, Morrison TH, et al. 2017. Coral reefs in the Anthropocene. Nature. 546(7656):82-90. https://doi.org/10.1038/nature22901

Iglesias-Prieto R, Trench RK. 1997. Acclimation and adaptation to irradiance in symbiotic dinoflagellates. II. Response of chlorophyll-protein complexes to different photon-flux densities. Mar Biol. 130(1):23-33. https://doi.org/10.1007/s002270050221

Jeffrey SW, Haxo FT. 1968. Photosynthetic pigments of symbiotic dinoflagellates (zooxanthellae) from corals and clams. Biol Bull. 135(1):149-165. https://doi.org/10.2307/1539622

Jeffrey SW, Humphrey GF. 1975. New spectrophotometric equations for determining chlorophylls $a, b, c_{1}$ and $c_{2}$ in higher plants, algae and natural phytoplankton. Biochem Physiol PFL. 167(2):191-194. https://doi.org/10.1016/S0015-3796(17)30778-3

LaJeunesse TC, Parkinson JE, Gabrielson PW, Jeong HJ, Reimer JD, Voolstra CR, Santos SR. 2018. Systematic revision of symbiodiniaceae highlights the antiquity and diversity of coral endosymbionts. Curr Biol. 28(16):2570-2580.

https://doi.org/10.1016/j.cub.2018.07.008 importancia para la formación local de los arrecifes y presentan una menor calcificación en contraste con otras regiones geográficas del planeta (Cabral-Tena et al. 2018), consideramos que el continuar el estudio de estos organismos, así como su protección local, resulta imprescindible para entender mejor la respuesta al estrés de las comunidades coralinas en esta región en escenarios de cambio global en el océano.

\section{Agradecimientos}

Este trabajo fue apoyado por el Consejo Nacional de Ciencia y Tecnología (CONACYT, México) a través del proyecto Ciencia Básica-2012, no. 181597, cuyo responsable fue EJCI. MADN recibió una beca doctoral (no. 486385) por parte del CONACYT para la realización de este estudio y agradece el apoyo brindado. Agradecemos a todos los estudiantes de la Universidad de Colima que nos apoyaron en los muestreos en campo y, especialmente, a Aramís Olivos-Ortíz del Centro Universitario de Investigaciones Oceanológicas por su ayuda en la determinación de la clorofila del agua de mar. Agradecemos a Mariana Delgado-Fernández por su ayuda en la elaboración del mapa del sitio de estudio.

Liñán-Cabello MA, Flores-Ramírez LA, Laurel-Sandoval MA, García-Mendoza E, Santiago-Soriano O, Delgadillo-Nuño MA. 2011. Acclimation in Pocillopora spp. during a coral restoration program in Carrizales Bay, Colima, Mexico. Mar Freshw Behav Phy. 44(1):61-72. https://doi.org/10.1080/10236244.2010.537440

Mayfield AB, Fan TY, Chen CS. 2013a. Physiological acclimation to elevated temperature in a reef-building coral from an upwelling environment. Coral Reefs. 32(4):909-921. https://doi.org/10.1007/s00338-013-1067-4

Mayfield AB, Fan TY, Chen CS. 2013b. Real-time PCR-based gene expression analysis in the model reef-building coral Pocillopora damicornis: Insight from a salinity stress study. Platax. 10:1-29. https://doi.org/10.29926/PLATAX.201312_2013.0001

Mayfield AB, Hsiao YY, Fan TY, Chen CS. 2012. Temporal variation in nucleic acid and protein ratios in four anthozoandinoflagellate endosymbioses of the Indo-Pacific: implications for molecular diagnostics. Platax. 9:1-24. https://doi.org/10.29926/PLATAX.201212.0001

Mayfield AB, Liu PJ, Wang YB, Chen CS. 2014a. Decreased green fluorescent protein-like chromoprotein gene expression in specimens of the model reef-building coral Pocillopora damicornis undergoing high temperature-induced bleaching. Platax. 11:1-23. https://doi.org/10.29926/PLATAX.201412_2014.0001

Mayfield AB, Wang YB, Chen CS, Lin CY, Chen SH. 2014b. Compartment-specific transcriptomics in a reef-building coral exposed to elevated temperatures. Mol Ecol. 23(23):5816-5830. https://doi.org/10.1111/mec.12982

Moya A, Tambutté S, Bertucci A, Tambutté E, Lotto S, Vullo D, Supuran CT, Allemand D, Zoccola D. 2008. Carbonic anhydrase in the scleractinian coral Stylophora pistillata-characterization, localization, and role in biomineralization. J Biol Chem. 283(37):25475-25484.

https://doi.org/10.1074/jbc.M804726200 
Muñiz-Anguiano D, Verduzco-Zapata M, Liñán-Cabello MA. 2017. Factores asociados a la respuesta de Pocillopora spp. (Anthozoa: Scleractinia) durante un proceso de restauración en la costa del Pacífico mexicano = Factors associated with response Pocillopora spp. (Anthozoa: Scleractinia) during a restoration process on the Mexican Pacific coast. Rev Biol Mar Oceanog. 52(2):299-310. http://dx.doi.org/10.4067/S0718-19572017000200009

Mydlarz LD, Fuess L, Mann W, Pinzón JH, Gochfeld DJ. 2016. Cnidarian immunity: from genomes to phenomes. In: Goffredo S, Dubinsky Z. (eds.), The Cnidaria, Past, Present and Future. Cham (Switzerland): Springer. p. 441-466. https://doi.org/10.1007/978-3-319-31305-4 28

Palumbi SR, Barshis DJ, Traylor-Knowles N, Bay RA. 2014. Mechanisms of reef coral resistance to future climate change. Science. 344(6186):895-898. https://doi.org/10.1126/science.1251336

Pinzón JH, LaJeunesse TC. 2011. Species delimitation of common reef corals in the genus Pocillopora using nucleotide sequence phylogenies, population genetics and symbiosis ecology. Mol Ecol. 20(2):311-325.

https://doi.org/10.1111/j.1365-294X.2010.04939.x

Poli D, Fabbri E, Goffredo S, Airi V, Franzellitti S. 2017. Physiological plasticity related to zonation affects hsp70 expression in the reefbuilding coral Pocillopora verrucosa. PlOS One. 12(2):e0171456. https://doi.org/10.1371/journal.pone.0171456
Reyes-Bonilla H, Escobosa-González LE, Cupul-Magaña AL, Medina-Rosas P, Calderón-Aguilera LE. 2013. Estructura comunitaria de corales zooxantelados (Anthozoa: Scleractinia) en el arrecife coralino de Carrizales, Pacífico Mexicano. Rev Biol Trop. 61(2):583-594. https://doi.org/10.15517/rbt.v61i2.11161

Schmittgen TD, Livak KJ. 2008. Analyzing real-time PCR data by the comparative $\mathrm{C}_{\mathrm{T}}$ method. Nat Protoc. 3(6):1101-1108. https://doi.org/10.1038/nprot.2008.73

Smith EG, D'Angelo C, Salih A, Wiedenmann J. 2013. Screening by coral green fluorescent protein (GFP)-like chromoproteins supports a role in photoprotection of zooxanthellae. Coral Reefs. 32(2):463-474. https://doi.org/10.1007/s00338-012-0994-9

Strickland JDH, Parsons T.R 1972. A Practical Handbook of Seawater Analysis. 2nd ed. Canada: Fisheries Research Board of Canada. Part IV.3, Pigment analysis; p. 185-197.

Vernon LP. 1960. Spectrophotometric determination of chlorophylls and pheophytins in plant extracts. Anal Chem. 32(9):1144-1150. https://doi.org/10.1021/ac60165a029

Veron J. 2000. Corals of the world. Townsville (Australia): Australian Institute of Marine Science. 1410 p.

Zamoum T, Furla P. 2012. Symbiodinium isolation by $\mathrm{NaOH}$ treatment. J Exp Biol. 215(22):3875-3880. https://doi.org/10.1242/jeb.074955

Received November 2019, accepted May 2020. 